University of Michigan Law School University of Michigan Law School Scholarship Repository

2011

\title{
Taxation as Regulation: Carbon Tax, Health Care Tax, Bank Tax and Other Regulatory Taxes
}

Reuven S. Avi-Yonah

University of Michigan Law School, aviyonah@umich.edu

Available at: https://repository.law.umich.edu/articles/1644

Follow this and additional works at: https://repository.law.umich.edu/articles

Part of the Legislation Commons, and the Tax Law Commons

\section{Recommended Citation}

Avi-Yonah, Reuven S. "Taxation as Regulation: Carbon Tax, Health Care Tax, Bank Tax and Other Regulatory Taxes." Acct. Econ. \& L. 1, no. 1 (2011): Article 6.

This Article is brought to you for free and open access by the Faculty Scholarship at University of Michigan Law School Scholarship Repository. It has been accepted for inclusion in Articles by an authorized administrator of University of Michigan Law School Scholarship Repository. For more information, please contact mlaw.repository@umich.edu. 


\section{Accounting, Economics, and Law}

A Convivium

Volume 1, Issue 1

2011

Article 6

\section{Taxation as Regulation: Carbon Tax, Health Care Tax, Bank Tax and Other Regulatory Taxes}

Reuven S. Avi-Yonah, University of Michigan

\section{Recommended Citation:}

Avi-Yonah, Reuven S. (2011) "Taxation as Regulation: Carbon Tax, Health Care Tax, Bank Tax and Other Regulatory Taxes," Accounting, Economics, and Law: Vol. 1: Iss. 1, Article 6.

DOI: $10.2202 / 2152-2820.1008$

(C2011 Convivium. All rights reserved. 


\title{
Taxation as Regulation: Carbon Tax, Health Care Tax, Bank Tax and Other Regulatory Taxes
}

\author{
Reuven S. Avi-Yonah
}

\begin{abstract}
This paper addresses three questions: 1. Is regulation a legitimate goal for taxation? 2. Which tax is best suited for regulation? 3. Would it be better to allocate just one goal per tax among the major taxes (individual and corporate income tax and VAT)? It then analyzes the proposed bank tax and the enacted health care tax as regulatory taxes, and concludes that the first is desirable (as is a carbon tax) but the second is not.
\end{abstract}

KEYWORDS: taxation, regulation, fiscal policy, carbon tax, health care tax, bank tax

JEL Classification Codes: H20 
Avi-Yonah: Taxation As Regulation

\section{TABLE OF CONTENTS}

1. INTRODUCTION

2. IS REGULATION A LEGITIMATE GOAL FOR TAXATION?

3. WHICH TAX IS BEST SUITED FOR REGULATION?

4. ALLOCATING ONE GOAL PER TAX?

5. CONCLUSION: The BanK TAX AND the HEalth CARE TAX 
Accounting, Economics, and Law, Vol. 1 [2011], Iss. 1, Art. 6

[A] tax is a pecuniary burden laid upon individuals or property for the purpose of supporting the Government ${ }^{l}$

[A] tax is not any less a tax because it has a regulatory effect ${ }^{2}$

\section{Introduction}

In his recent decision refusing to dismiss the Commonwealth of Virginia's challenge to the constitutionality of the Patient Protection and Affordable Health Care Act, Judge Henry Hudson of the U.S. District Court for the Eastern District of Virginia laid out two competing visions of taxation. The context was the imposition by Congress of a monetary penalty on individuals who refuse to buy health insurance. The Commonwealth argued that calling this levy a tax, as Congress did, added nothing to its constitutional validity since "the noncompliance penalty... does not meet the historical criteria for a tax" because "the clear purpose of the assessment is to regulate conduct, not generate revenue for the government." 3 On the other hand, the Federal Government argued that taxation has frequently been used for regulatory purposes, and that "[i]t is beyond serious question that a tax does not cease to be valid merely because it regulates, discourages, or even definitely deters the activities taxed." 4 Which side is right?

Taxation has two well-known goals. ${ }^{5}$ Undoubtedly, as suggested by the first quotation above, the first and most widely accepted one is to raise revenue for necessary government functions. Although there is a broad debate about which governmental functions are truly indispensable, most commentators would agree that raising revenue is an indispensable feature of governments and that a government that is unable to collect taxes, like the Russian government almost was in 1998 , is unlikely to survive.

The second and more controversial goal of taxation is redistribution. Most developed countries see the tax system as a way to redistribute income from the rich to the poor. The desirability of redistribution has been controversial, but most commentators agree that if redistribution is a legitimate government goal, then taxation may be the most effective way to achieve that goal.

But taxation has a third goal, which has not been noticed as widely: a regulatory goal. In most developed countries governments use the tax system to change the behavior of actors in the private sector, by incentivizing (subsidizing)

\footnotetext{
${ }^{1}$ United States v. Reorganized CF\&I Fabricators of Utah, Inc., 518 U.S. 213, 224 (1996).

${ }^{2}$ Sonzinsky v. United States, 300 U.S. 506, 513 (1937).

${ }^{3}$ Virginia v. Sebelius, Mermorandum opinion, Eastern Dist., Va., Civil Action No. 3:10CV188HEH (August 2, 2010), 26-27.

${ }^{4}$ Id., 29, citing United States v. Sanchez, 340 U.S. 42, 44 (1950).

${ }^{5}$ For a longer discussion, see Avi-Yonah, The Three Goals of Taxation, 60 Tax L. Rev. 1 (2007)
} 
activities they wish to promote and by disincentivizing (penalizing) activities they wish to discourage. This is the point of the second quotation above.

This regulatory function of the tax system is quite well established. Indeed, it can be argued that some types of taxes, such as Pigouvian taxes (designed to deter certain activities by forcing private actors to internalize their social costs), are entirely regulatory in nature. In other cases, such as the corporate income tax, much of the complexity of the current tax structure stems from the government's attempting to use it to achieve regulatory aims. If the US income tax was purely a revenue raising and redistributive tax, most of the complexity of the current tax code could be eliminated.

Precisely for this reason, most commentators have decried the use of taxation for regulatory purposes. Regulation, they argue, should either be done directly, or if it is desirable that it be done via subsidies or penalties, those should be delivered directly as well by other government agencies. The IRS should be left to its proper role of collecting revenues, with a possible side role in achieving redistribution.

This argument underlies the long debate over the US tax expenditure budget. As originally conceived by Stanley Surrey in the 1960s, the tax expenditure budget (which has been a feature of US budgets since 1974) was intended to single out all the instances in which the tax code is used for regulatory purposes. However, the tax expenditure budget has been controversial from the beginning, with critics charging that it is impossible to define an objective, nonpolitical baseline against which to measure tax expenditures. Recently, this has led the Joint Committee on Taxation to redefine tax expenditures as any deviation not from an objective baseline but from the language of other provisions of the code. ${ }^{6}$ The committee eventually reversed course and returned to the original definition of tax expenditures, but the debate will continue.

This essay will discuss the regulatory role of taxation. First, it will argue that regulation is a legitimate role of taxation and that in some cases taxes are a superior vehicle compared to other regulatory techniques. Second, it will ask which of the current taxes in developed countries are best suited for achieving regulatory goals. Finally, it will argue that in general, using only one form of tax for each goal should permit us to simplify the others. In conclusion, we will examine two current proposals for regulatory taxation in the context of financial

\footnotetext{
${ }^{6}$ Edward Kleinbard, "Tax Expenditure Framework Legislation”, 63 National Tax Journal 353 (June 2010); see also Edward Kleinbard, "The Congress Within a Congress: How Tax Expenditures Distort Our Budget and Our Political Process", 36 Ohio Northern University Law Review 1 (2010) ; but see Robert Peroni and J. Clifford Fleming, Jr., Can Tax Expenditure Analysis Be Divorced from a Normative Tax Base?: A Critique of the 'New Paradigm' and its Denouement 30 Virginia Tax Review (2010).
} 
and health care reform, and argue that while one is a proper use of taxation as regulation, the other is not.

\section{Is Regulation a Legitimate Goal for Taxation?}

This essay will argue that in some cases regulation is a legitimate goal of taxation. In general, the choice between taxation and other forms of regulation, such as command and control regulation or direct subsidies, depends on the particular policy context. In some instances, taxation is the most effective way to achieve a specific regulatory goal.

A good example of this is combating global climate change. There are three broad methods that have been advanced for government to reduce greenhouse gas emissions: Command and control regulation, cap and trade, and carbon taxes. Of these, there is a broad consensus among commentators that carbon taxes are the most effective. ${ }^{7}$

Command and control regulation of greenhouse gas emissions has generally been rejected because of a wide consensus that the government does not have the necessary information to ensure that the emissions targets are distributed most effectively among private market actors. The solution to the climate change problem depends on technological innovation in the private sector, and governments are ill-suited to picking winners to develop such technologies. In addition, existing command and control regimes are sector specific while the climate change problem applies to the entire economy.

This leaves cap and trade and carbon taxes as the two leading marketbased solutions. However, a carbon tax is much simpler than cap and trade. A tax is imposed at \$x per ton of carbon content on the main sources of carbon dioxide emissions in the economy, namely coal, oil, and natural gas. The tax is imposed "upstream," i.e., at the point of extraction or importation, which means than it can be imposed on only 2,000 taxpayers (500 coal miners and importers, 750 oil producers and importers, and 750 natural gas producers and importers). Credits can be given to carbon sequestration projects and to other projects that reduce greenhouse gas emissions, and exports are exempted.

Cap and trade, on the other hand, is inherently more complicated. While the cap can also be imposed "upstream", it has several features that require complexity. First, the proposal needs to determine how allowances will be created and distributed, either for free or by auction. Free distribution requires deciding which industries receive allowances, while an auction requires a complex monitoring system to prevent cheating. Second, the trading in allowances needs to

\footnotetext{
${ }^{7}$ See Avi-Yonah and Uhlmann, "Combating Global Climate Change: Why a Carbon Tax Is a Better Response to Global Warming than Cap and Trade", 28 Stan. Envir. L. J. 3 (2009)
} 
be set up and monitored: a system needs to be devised to prevent the same allowance from being used twice, and penalties need to be established for polluters who exceed their allowances. Third, if allowances are to be traded with other countries, the international trading of allowances would need to be monitored as well. Fourth, to prevent cost uncertainty, cap and trade proposals typically have complex provisions for banking and borrowing allowances, and some of them provide for safety valves. Fifth, offsets are needed for carbon sequestration and similar projects, and those are more complicated than credits against a carbon tax liability. Finally, most cap and trade proposals involve provisions for coordinating with the cap and trade policies of other countries, and for punishing countries that do not have a greenhouse gas emission reduction policy.

In addition to its inherent complexity, cap and trade is also more difficult to enforce. An elaborate mechanism needs to be set up to distribute and collect allowances and to ensure that allowances are real (a difficult task, especially if allowances from non-United States programs are permitted) and that polluters are penalized it they emit greenhouses gases without an allowance. A new administrative body needs to be set up for this purpose, or at least a new office within EPA, and new employees with the relevant expertise need to be hired. A carbon tax, on the other hand, can be enforced by the IRS with its existing staff, which has the relevant expertise in enforcing other excise taxes.

Cap and trade also raises collateral issues that are not present in a carbon tax, such as the need for the SEC to enforce rules regarding futures trading in allowances. A good example is the tax implications of both policies. A carbon tax, as a federal tax, has no tax implications: it is simply collected and is not deductible. Allowances under cap and trade, on the other hand, raise a multitude of tax issues: What are the tax implications of distributing allowances for free? What are the tax implications of trading in allowances? Should allowance exchanges be permitted to avoid the tax on selling allowances? What amount of the purchase price of a business should be allocated to its allowances? If borrowing and banking occur, what are the tax consequences? Can allowances be amortized? None of these issues arise under a carbon tax.

It can in fact be argued that the tax implications of cap and trade are inconsistent with the basic premise of the system. The theory behind cap and trade posits that permits to emit $\mathrm{CO} 2$ will be traded freely among private market participants, so that they end up distributed in the most efficient way (i.e., in the hands of companies whose costs of abating emissions are the highest). This is consistent with the Coase Theorem because in the absence of transaction costs the initial allocation of permits does not matter. However, there are likely to be significant transaction costs, including the application of the corporate tax. Under current tax rules companies are likely to face a tax burden when they (a) receive 
permits, (b) sell permits, (c) borrow permits, (d) bank permits, and (e) when a business that has permits is bought or sold. These barriers mean that the Coase Theorem does not apply and the initial allocation matters. ${ }^{8}$ This problem can be mitigated by changing the Code to provide for tax-free trading in permits, but other tax-related transaction costs are likely to persist in any cap and trade regime. Therefore, a carbon tax emerges as the superior price mechanism to restrict carbon emissions.

This example illustrates that at least in one important policy context, taxation is not just an acceptable vehicle for regulation, but the regulatory technique that is preferred by most commentators (even though it may be less realistic politically). Another example of a preference for taxation is Pigouvian taxes on items like tobacco and alcohol, which are designed to reduce behavior that has important negative externalities. The experience with Prohibition has clearly demonstrated that taxation is superior to direct regulation in reducing alcohol consumption, and taxation of cigarettes has been the most effective technique in reducing smoking.

These taxes are relatively marginal in the tax systems of developed economies. But it is also clear that developed countries also use their main taxes, which are the individual and corporate income taxes and the VAT, to achieve regulatory goals. Given that regulation via taxation is legitimate in some cases, the next section will address which of these taxes is best suited to achieve regulatory goals.

\section{Which Tax is Best Suited for Regulation?}

One of the remarkable examples of convergence in comparative taxation is that most countries rely primarily on three types of tax- the individual income tax, the corporate income tax, and the value added tax. While the weight of each tax in total revenue varies (in general, developing countries rely more on the VAT and the corporate tax than on the individual income tax), the vast majority of countries have all three taxes.

The reason for this phenomenon is that each tax is best suited to one of the three goals of taxation mentioned above, and that most countries adopt all three goals. If your main goal is raising revenue to fund the government, the best instrument is the VAT. Because an invoice-credit, destination-based VAT relies

\footnotetext{
${ }^{8}$ Ethan Yale has argued that the tax on selling permits can be offset by deducting the costs of avoiding pollution when permits are sold. See Ethan Yale, Taxing Cap and Trade Environmental Regulation, 37 Journal of Legal Studies 535 (2008). However, this only applies when borrowing and banking permits are not permitted, which seems unlikely, and it assumes that all pollution avoidance costs are currently deductible, which would also require changes in current law.
} 
heavily on the private sector to monitor its collection, even developing countries with weak tax administrations can collect significant revenues from the VAT. Much of it is collected at the border on imports, and the rest is collected on business-to-business transactions in which the buyer has an interested in making sure that the seller paid tax to obtain input credits.

By contrast, the corporate income tax and the individual income tax are less effective at raising revenue. Corporate income taxation requires a sophisticated tax administration and is open to avoidance by techniques such as thin capitalization and transfer pricing. In addition, most corporate income tax is collected from multinational enterprises, and countries that wish to attract MNEs use tax incentives, a form of tax competition that reduces revenues. As for the individual income tax, most developing countries are unable to enforce it on anyone but wage earners, and even developed countries have a hard time preventing tax evasion by taxpayers with mobile income.

For redistributive purposes, however, the individual income tax is best, and redistribution is the main reason why this tax is used by developed countries and nominally even by developing countries (although they may not be able to enforce it, the tax has an important symbolic value). The VAT is inherently regressive and cannot reach wealth that is not consumed, while the corporate tax is a poor vehicle for redistribution because of the uncertainty about its incidence. This leaves the individual income tax as the main vehicle for redistribution in developed countries, and US data indicate that the tax is in fact quite progressive and able to achieve significant redistribution.

This leaves the regulatory function of taxation, and here it is the corporate tax that is best suited to fulfill this function. The main reason is that corporations are major players in the economy of every country, and that there are relatively few of them, so that it is possible to achieve regulatory goals with minimal administrative efforts by focusing on the corporate sector. The carbon tax, for example, is to be levied only on about 2000 oil, gas and coal producers and importers, all of whom are corporations. These 2000 corporations will pass the tax burden downstream where it will ultimately influence consumer behavior, but the regulatory structure that is needed to police the tax is much simpler than if the government wanted to monitor consumers directly.

Thus, because each tax is best suited to fulfill one of the three goals of taxation, most countries use all three. As the US is now finding out, it is very difficult to collect sufficient revenue from taxation without using a VAT, which is why the VAT has now been adopted by every other member of the OECD. Redistribution is very difficult without an effective personal income tax, and that is a major reason for the greater inequality in developing than in developed countries. And the persistence of the corporate tax despite widespread calls to abolish it stems from its effectiveness as a regulatory vehicle. We could easily 
replace the revenue of our corporate tax by a small VAT, and it is not effective for redistribution because its incidence is unknown and probably shifting. But we are very unlikely to be able to achieve the regulatory goals of taxation without a corporate tax.

\section{Allocating One Goal per Tax?}

Would it be possible to go further and simplify each tax if we were clear about its main goal? I believe the answer is yes, at least to a significant extent.

The clearest example of goal confusion is the individual income tax in the US. Because we do not have a VAT, we must rely on the individual tax for most of our revenue. In addition, Congress in recent years has added a multitude of special credits to the individual tax to incentivize a myriad of desirable activities such as education, energy saving, saving for retirement and the like.

I believe we could achieve significant simplification of the individual tax if we gave up on its revenue and regulatory potential. For revenue, as Michael Graetz has suggested, we could substitute a VAT and exempt from tax anyone but the rich. ${ }^{9}$ Anyone earning below $\$ 100,000$ consumes most of their income and would benefit from eliminating the income tax.

In addition, most of the criticism of tax expenditures is focused on the individual tax provisions. They are very complex, difficult for ordinary taxpayers to use, and cumbersome for the IRS to administer. In most cases, we would save transaction costs by converting the tax expenditure to a direct subsidy, e.g., for tuition or for energy saving equipment. These subsidies could be delivered to colleges and producers, rather than funneled via the individual tax system.

Similarly, the VAT in many countries is made needlessly complex by an attempt to mitigate its regressivity by exempting certain products such as food, clothing or medicine, or by having multiple rates. Once the VAT is conceived as a pure revenue raiser, it can be made as broad as possible with a single rate. Regressivity should be addressed via the income tax system or by sending low income taxpayers rebate checks, as well as through the expenditure side of the budget.

Finally, a lot of the trouble people have with the corporate tax system stems from a misunderstanding of its primarily regulatory nature. Once we understand that the main purpose of the corporate tax is to regulate corporate behavior, the key issue becomes not how much revenue is raised, or what the incidence of the tax may be, but rather whether the tax is effective in achieving its regulatory goals. It may be, for example, perfectly acceptable for a large

\footnotetext{
${ }^{9}$ Michael J. Graetz, 100 Million Unnecessary Returns: A Simple, Fair, and Competitive Tax Plan for the United States (Yale University Press 2007).
} 
Avi-Yonah: Taxation As Regulation

corporation to pay no tax, as long as the reason for this is consistent with Congress' intent in allowing it certain exemptions or deductions. The newly codified economic substance doctrine, for example, is misguided because it focuses on the business purpose of the corporate taxpayer, rather than on Congressional intent.

\section{Conclusion: The Bank Tax and the Health Care Tax}

Two current examples can illustrate the distinction between effective and less effective uses of taxation as a regulatory instrument: the proposed bank tax and the enacted health care tax.

The bank tax falls squarely within the realm of effective uses of taxation to regulate. It is imposed on financial institutions' capital at risk, excluding federally insured deposits, and it is designed to deter banks from taking excessive risks. The bank tax is imposed on a relatively small number of sophisticated taxpayers and is not particularly complicated. It can serve as an offset to the numerous ways in which banks are currently subsidized by the tax system, including the ability to deduct bad loan reserves, to defer tax on interest earned overseas, and to acquire other banks and be able to use their losses to offset future income. The bank tax represents a small repayment of the funds expended by taxpayers to rescue the major banks during the crisis of 2008 , and it is well designed to target only those institutions that are deemed "too big to fail."

The health care tax, on the other hand, stems primarily from the desire to ensure the constitutionality of the individual health insurance mandate. It is really a penalty for individuals who do not purchase health insurance. It is relatively complex, with difficult definitions that govern the level of the penalty. It applies to many taxpayers, but exempts those who are covered through their employers, so that it falls disproportionately on the poor. It is likely to be as difficult to enforce as the Earned Income Tax Credit, for the same reason.

Moreover, the two taxes have different signaling effects. Calling the bank tax a tax rather than a fee or premium is reasonable, because it does not represent payment for insurance. Calling the health insurance penalty a tax, however, may dilute its effect, because people tend to have a different reaction to not paying taxes than to avoiding penalties. One of the main concerns regarding the health care tax is that people would prefer to pay it rather than obtain insurance, and calling it a tax does nothing to mitigate this concern.

In general, taxation as regulation makes sense when (1) it is applied to small numbers of taxpayers, (2) the taxpayers are sophisticated and able to deal with complex tax incentives, (3) the regulatory goal is clear and related to the level of the tax. The bank tax, the carbon tax, and other forms of corporate taxation meet these criteria, but the health care tax and many tax expenditures of 
the individual income tax do not. In general, Congress should limit its regulatory activities to the corporate tax, apply the individual income tax to the rich as a vehicle for redistribution, and enact a VAT to raise revenue.

\section{Legal Cases}

Sonzinsky v. United States, 300 U.S. 506, 513 (1937).

United States v. Reorganized CF\&I Fabricators of Utah, Inc., 518 U.S. 213, 224 (1996)

United States v. Sanchez, 340 U.S. 42, 44 (1950).

Virginia v. Sebelius, Memorandum opinion, Eastern Dist., Va., Civil Action No. 3:10CV188-HEH (August 2, 2010), 26-27.

\section{References}

Avi-Yonah, Reuven (2007). "The Three Goals of Taxation," 60 Tax L. Rev. 1 (2007)

Avi-Yonah, Reuven and Uhlmann (2009), "Combating Global Climate Change: Why a Carbon Tax Is a Better Response to Global Warming than Cap and Trade", 28 Stan. Envir. L. J. 3 (2009)

Graetz, Michael J. (2007) 100 Million Unnecessary Returns: A Simple, Fair, and Competitive Tax Plan for the United States (Yale University Press 2007).

Kleinbard, Edward (2010) "Tax Expenditure Framework Legislation”, 63 National Tax Journal 353 (June 2010)

Kleinbard, Edward (2010) "The Congress Within a Congress: How Tax Expenditures Distort Our Budget and Our Political Process", 36 Ohio Northern University Law Review 1 (2010)

Peroni, Robert and J. Clifford Fleming, Jr. (2010), "Can Tax Expenditure Analysis Be Divorced from a Normative Tax Base?: A Critique of the 'New Paradigm' and its Denouement," 30 Virginia Tax Review (2010).

Yale, Ethan (2008) "Taxing Cap and Trade Environmental Regulation," 37 Journal of Legal Studies 535 (2008). 